\title{
Genetics of the Dombrock Blood Group System
}

\author{
PATRICIA TIPPETT
}

From the Medical Research Council Blood Group Research Unit, The Lister Institute, Chelsea Bridge Road, London S.W.I

In April 1965, anti-Doa, an antibody defining a 'new' red cell antigen, was reported (Swanson, Polesky, Tippett, and Sanger, 1965). The present paper records the results of tests with anti-Do ${ }^{a}$ on samples received in this unit from October 1964 until April 1966.

Anti-Do ${ }^{a}$ reacts best by the antiglobulin test on papainized cells, but only a minority of otherwise good antiglobulin sera are suitable. The $\gamma \mathrm{G}$ or $\gamma$ $M$ reputations of antiglobulin sera have not, so far, provided a guide for finding a suitable reagent. A second example of anti-Do (Webb, Lockyer, and Tovey, 1966) behaves in the same way.

\section{Frequencies}

The results of testing unrelated people in three populations are given in Table I. The figures for people of Northern European ancestry include 423 reported at Strasbourg (Tippett, Sanger, Swanson, and Polesky, 1967). The gene frequencies are calculated on the assumption that the antigen $\mathrm{Do}^{\mathrm{a}}$ is a dominant character. It is seen in Table I that the gene frequencies for the Israelis are very similar to those for the Northern Europeans; on the other hand, 76 Negroes show a lower incidence of the gene $D o^{a}$, which agrees with the findings of Polesky and Swanson (1966).

Received August 18, 1966.

\section{Inheritance}

From the Northern European genotype frequencies the expected incidence of the six genotypically and the three phenotypically different matings can be calculated, together with the children expected therefrom (Table II).

In Table III the calculated Northern European phenotype frequencies are applied to the results of testing 201 Northern European families. The agreement between observed and expected children is close, confirming the dominant character of the $\mathrm{Do}^{\mathrm{a}}$ antigen.

Because of the wide variation of family size, from I to ro children, Fisher's (1939) method for analysing the blood groups of families was also applied to these data. In Table IV the details of the 201 Northern European families are recorded. Applying Fisher's formulae to the $\operatorname{Do}(a+) \times \operatorname{Do}(a+)$ matings of Table IV the expected number of families of various sizes in which all children are $\mathrm{Do}(\mathrm{a}+)$ can be calculated; similar analysis is applied to the $\operatorname{Do}(a+) \times \operatorname{Do}(a-)$ matings. A summary of the analysis of these 201 families is given in Table V.

Details of 76 Israeli families with 224 children are given in Table VI, and a summary of their analysis in Table VII.

There is very close agreement between the expected and observed number of families in the four categories, both for the Northern Europeans and for the Israelis. Thus, tests on families show that the anti-

TABLE I

INCIDENCE OF DOMBROCK GROUPS IN UNRELATED PEOPLE

\begin{tabular}{|c|c|c|c|c|c|c|c|c|}
\hline & \multirow{2}{*}{$\begin{array}{l}\text { No. } \\
\text { Tested }\end{array}$} & \multicolumn{2}{|c|}{ Phenotypes } & \multicolumn{2}{|c|}{ Genes } & \multicolumn{3}{|c|}{ Genotypes } \\
\hline & & $\mathrm{Do}(\mathrm{a}+)$ & $\operatorname{Do}(a-)$ & $D o^{\mathrm{a}}$ & Do & $D o^{\mathrm{a}} D o^{\mathrm{a}}$ & $D o^{2} D o$ & DoDo \\
\hline $\begin{array}{l}\text { Northern-European } \\
\text { Israeli } \\
\text { Negro }\end{array}$ & $\begin{array}{l}755 \\
128 \\
76\end{array}$ & $\begin{array}{c}501 \\
66 \cdot 36 \% \\
83 \\
64 \cdot 84 \% \\
34 \\
44 \cdot 74 \%\end{array}$ & $\begin{array}{c}254 \\
33 \cdot 64 \% \\
45 \\
35 \cdot 16 \% \\
42 \\
55 \cdot 26 \%\end{array}$ & $\begin{array}{l}0.420 \\
0.407 \\
0.257\end{array}$ & $\begin{array}{l}0.580 \\
0.593 \\
0.743\end{array}$ & $\begin{array}{l}0.176 \\
0.166 \\
0.066\end{array}$ & $\begin{array}{l}0.487 \\
0.483 \\
0.382\end{array}$ & $\begin{array}{l}0.336 \\
0.351 \\
0.552\end{array}$ \\
\hline
\end{tabular}


TABLE II

EXPECTED DISTRIBUTION OF DOMBROCK GROUPS IN NORTHERN-EUROPEAN PARENTS AND OFFSPRING

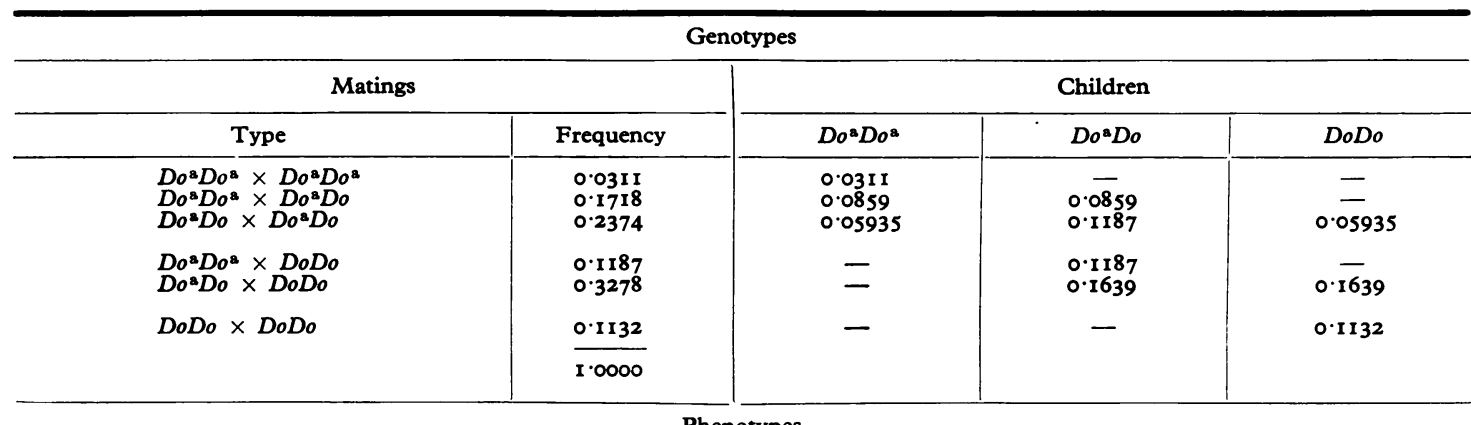

\begin{tabular}{|c|c|c|c|}
\hline \multicolumn{4}{|c|}{ Phenotypes } \\
\hline \multicolumn{2}{|c|}{ Matings } & \multicolumn{2}{|c|}{ Proportion of Children from Each Mating } \\
\hline Type & Frequency & $\operatorname{Do}(a+)$ & $\operatorname{Do}(a-)$ \\
\hline $\begin{array}{l}\operatorname{Do}(a+) \times \operatorname{Do}(a+) \\
\operatorname{Do}(a+) \times \operatorname{Do}(a-) \\
\operatorname{Do}(a-) \times \operatorname{Do}(a-)\end{array}$ & $\begin{array}{l}0.4403 \\
0.4465 \\
0.1132 \\
1.0000\end{array}$ & $\begin{array}{l}0.8652 \\
0.6329\end{array}$ & $\begin{array}{l}0.1348 \\
0.3671 \\
I .0000\end{array}$ \\
\hline
\end{tabular}

gen $\mathrm{Do}^{\mathrm{a}}$ is inherited as an autosomal dominant character. A small number of families from other races also conform: 25 Greek, II Sardinians, 4 Polish, 2 Negro, and 2 Japanese.

Genetical Independence of Antigen Doa. It is easy to show that a new antibody differs in specificity from those already known, but not so easy to show that the antigen which it defines is not a previously unrecognized part of one of the old systems. This has to be done by testing family after family until examples are found in which the antigen can be seen to segregate away from the established systems. Some of the families mentioned in the previous section and some incomplete families, lacking one parent, showed informative segregation.

Genetic recombination in the families shows that the gene $D o^{\mathrm{a}}$ is not sited at the loci for any of the established red cell systems: ABO, MNSs, $P, R h$, Lutheran, Kell, Lewis, Duffy, Kidd, Yt, or for the secretor system, and that it is not X-or Y-linked. Recombination also dissociates the locus for $\mathrm{Do}^{\mathrm{a}}$ from the loci for the following genetic characters of the blood: haptoglobins, acid phosphatase, phosphoglucomutase, 6-phosphogluconate dehydrogenase, lactate dehydrogenase, serum cholinesterase $E_{1}$ and $\mathrm{C}_{5}$, adenylate kinase.

$D o^{\mathrm{a}}$ has not yet been shown to segregate away from the Auberger genes. Unhappily the few available families known to segregate for Auberger did not segregate for Dombrock. However, the incidence of $\mathrm{Do}(\mathrm{a}+)$ and $\mathrm{Do}(\mathrm{a}-)$ within $\mathrm{Au}(\mathrm{a}+)$ and $\mathrm{Au}(\mathrm{a}-)$ groups does not differ significantly from that in the general population.

TABLE III

DOMBROCK GROUPS OF 20I NORTHERN-EUROPEAN FAMILIES WITH 573 CHILDREN

\begin{tabular}{|c|c|c|c|c|c|c|c|c|}
\hline \multicolumn{4}{|c|}{ Matings } & \multicolumn{5}{|c|}{ Children } \\
\hline \multirow{2}{*}{ Type } & \multicolumn{2}{|c|}{ Ni mber } & \multirow[b]{2}{*}{$x^{2}$} & \multirow[t]{2}{*}{ Total } & \multicolumn{2}{|c|}{$\operatorname{Do}(a+)$} & \multicolumn{2}{|c|}{$\operatorname{Do}(a-)$} \\
\hline & Obs. & Exp. & & & Obs. & Exp. & Obs. & Exp. \\
\hline \multirow[t]{2}{*}{$\begin{array}{l}\operatorname{Do}(a+) \times \operatorname{Do}(a+) \\
\operatorname{Do}(a+) \times \operatorname{Do}(a-) \\
\operatorname{Do}(a-) \times \operatorname{Do}(a-)\end{array}$} & $\begin{array}{l}77 \\
98 \\
26\end{array}$ & $\begin{array}{l}88 \cdot 5 \\
89 \cdot 7 \\
22 \cdot 8 \\
\end{array}$ & $\begin{array}{l}1 \cdot 49 \\
0.77 \\
0.45 \\
\end{array}$ & $\begin{array}{r}216 \\
270 \\
87\end{array}$ & $\begin{array}{r}192 \\
177 \\
I *\end{array}$ & $\begin{array}{c}186.9 \\
170.9 \\
0\end{array}$ & $\begin{array}{l}24 \\
93 \\
86\end{array}$ & $\begin{array}{l}29 \cdot 1 \\
99 \cdot 1 \\
89\end{array}$ \\
\hline & 201 & & $2 \cdot 71$ & & & & & \\
\hline
\end{tabular}

- Presumed extramarital 
TABLE IV

DETAILS OF 20I NORTHERN EUROPEAN FAMILIES WITH 573 CHILDREN

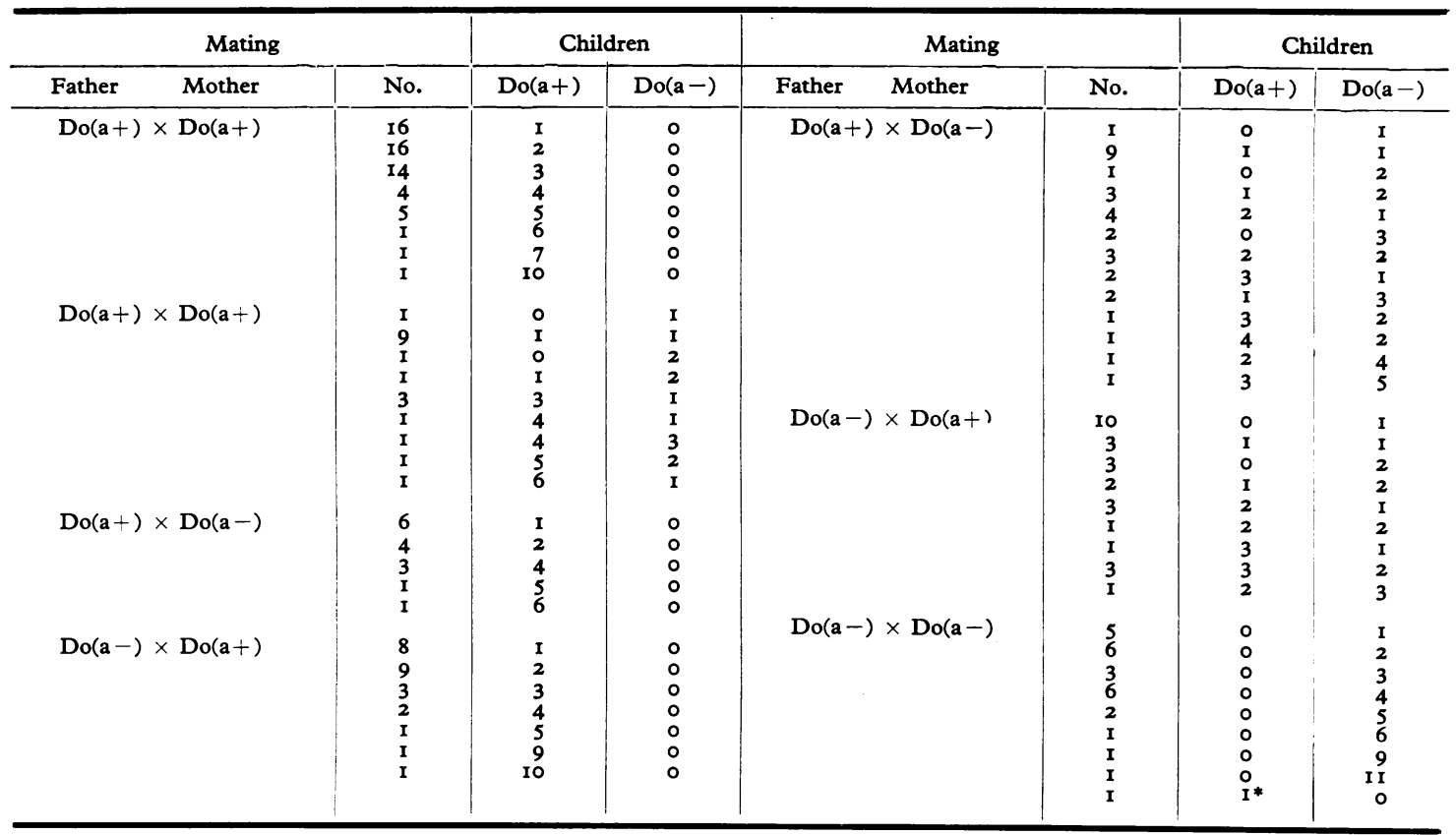

* Presumed extramarital.

Linkage Tests. In the search for linkage between the Dombrock locus and those for other blood group systems and for the biochemical genetic characters of the blood, families with at least one doubly heterozygous parent were analysed by the lod score method of Morton (1955), as instructed by Maynard Smith, Penrose, and Smith (196I).

Renwick and Schulze (1965) and Cook (1965) found evidence that recombination was more frequent in women than in men; therefore, families scored through the father are considered separately from those scored through the mother. The sum of the lod scores, $Z\left(\theta^{\prime}\right)$ for the doubly heterozygous father and $Z(\theta)$ for the doubly heterozygous mother, for each system is given in Table VIII.

Morton (1955) considers linkage to be present when $Z\left(\theta^{\prime}, \theta\right)>3$ and that linkage is absent if $Z$ $\left(\theta^{\prime}, \theta\right)<-2$. The Dombrock locus is therefore not closely linked to the blood group loci for ABO, MNSs, $\mathrm{P}, \mathrm{Rh}$, Lutheran, or Kidd, and probably not closely linked to the loci for Kell, Duffy, Yt, ABH in saliva, or Le $e^{a}$ in saliva. Neither is the Dombrock locus closely linked to the loci for any of the other genetical markers investigated: haptoglobins, acid

TABLE V

SUMMARY OF ANALYSIS BY FISHER'S METHOD OF NORTHERN-EUROPEAN FAMILIES

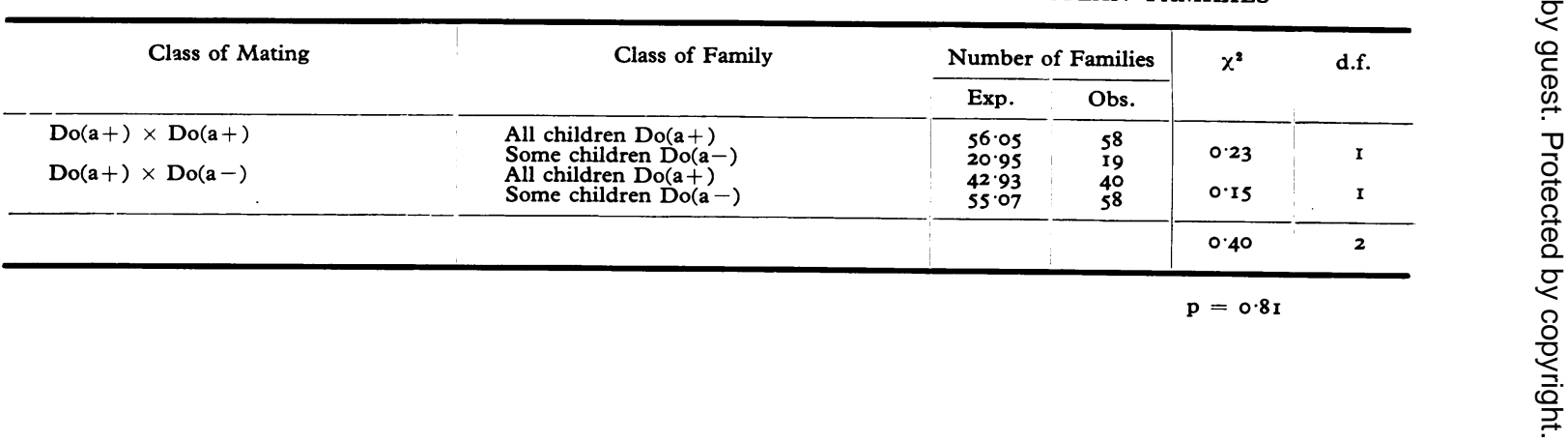


* Presumed extramarital.

TABLE VII

SUMMARY OF ANALYSIS BY FISHER'S METHOD OF ISRAELI FAMILIES

\begin{tabular}{|c|c|c|c|c|c|}
\hline \multirow{2}{*}{ Class of Mating } & \multirow{2}{*}{ Class of Family } & \multicolumn{2}{|c|}{ Number of Families } & \multirow{2}{*}{$x^{2}$} & \multirow{2}{*}{ d.f. } \\
\hline & & Exp. & Obs. & & \\
\hline \multirow[t]{2}{*}{$\begin{array}{l}\operatorname{Do}(a+) \times \operatorname{Do}(a+) \\
\operatorname{Do}(a+) \times \operatorname{Do}(a-)\end{array}$} & \multirow[t]{2}{*}{$\begin{array}{l}\text { All children Do(a }+) \\
\text { Some children Do(a-) } \\
\text { All children Do(a+) } \\
\text { Some children Do(a-) }\end{array}$} & \multirow[t]{2}{*}{$\begin{array}{r}20 \cdot 42 \\
7 \cdot 58 \\
16 \cdot 71 \\
23 \cdot 29\end{array}$} & \multirow[t]{2}{*}{$\begin{array}{r}21 \\
7 \\
15 \\
25\end{array}$} & $\begin{array}{l}0.06 \\
0.33\end{array}$ & $\begin{array}{l}\mathbf{I} \\
\mathbf{I}\end{array}$ \\
\hline & & & & 0.39 & 2 \\
\hline
\end{tabular}

FAILURE TO DETECT LINKAGE BETWEEN DOMBROCK LOCUS AND LOCI FOR OTHER GENETIC CHARACTERS OF BLOOD: A SUMMARY OF LOD SCORES

\begin{tabular}{|c|c|c|c|c|c|c|c|c|c|c|c|c|}
\hline \multirow{2}{*}{ Blood Groups } & \multirow{2}{*}{$\begin{array}{l}\text { No. of } \\
\text { Scoring } \\
\text { Families }\end{array}$} & \multicolumn{5}{|c|}{ Paternal Recombination Fraction, $\theta^{\prime}$} & \multirow{2}{*}{$\begin{array}{l}\text { No. of } \\
\text { Scoring } \\
\text { Families }\end{array}$} & \multicolumn{5}{|c|}{ Maternal Recombination Fraction, $\theta$} \\
\hline & & 0.05 & $0 \cdot 1$ & 0.2 & 0.3 & 0.4 & & 0.05 & 0.1 & 0.2 & 0.3 & 0.4 \\
\hline $\begin{array}{l}\text { ABO } \\
\text { MNSs } \\
\text { P } \\
\text { Rh } \\
\text { Lutheran } \\
\text { Kell } \\
\text { Duffy } \\
\text { Kidd } \\
\text { Yt } \\
\text { ecretion Le } \\
\text { ABH secretion } \\
\text { Other characters }\end{array}$ & $\begin{array}{r}28 \\
30 \\
5 \\
27 \\
3 \\
4 \\
12 \\
13 \\
2 \\
1 \\
2 \\
0\end{array}$ & $\begin{array}{r}-24.250 \\
-11.253 \\
-3.694 \\
-13.185 \\
-3.396 \\
-2.307 \\
-1.917 \\
-6.859 \\
-2 \cdot 163 \\
-0.769 \\
-1 \cdot 145\end{array}$ & $\begin{array}{r}-14.474 \\
-5.014 \\
-2.110 \\
-6.404 \\
-2 \cdot 042 \\
-1.302 \\
-0.401 \\
-3 \cdot 790 \\
-1 \cdot 331 \\
-0.482 \\
-0.635\end{array}$ & $\begin{array}{l}-6.079 \\
-0.559 \\
-0.788 \\
-1.418 \\
-0.858 \\
-0.488 \\
+0.486 \\
-1.319 \\
-0.582 \\
-0.216 \\
-0.226\end{array}$ & $\begin{array}{l}-2.454 \\
+0.540 \\
-0.255 \\
+0.111 \\
-0.345 \\
-0.167 \\
+0.471 \\
-0.406 \\
-0.227 \\
-0.086 \\
-0.072\end{array}$ & $\begin{array}{l}-0.722 \\
+0.382 \\
-0.048 \\
+0.280 \\
-0.074 \\
-0.035 \\
+0.180 \\
-0.101 \\
-0.053 \\
-0.020 \\
-0.015\end{array}$ & $\begin{array}{r}17 \\
23 \\
3 \\
21 \\
1 \\
1 \\
14 \\
8 \\
1 \\
1 \\
3\end{array}$ & $\begin{array}{r}-12.407 \\
-13.880 \\
-2.012 \\
-12.775 \\
-0.769 \\
-0.658 \\
-9.380 \\
-4.810 \\
-1.906 \\
-0.769 \\
-2.083\end{array}$ & $\begin{array}{l}-7 \cdot 167 \\
-7 \cdot 458 \\
-1 \cdot 006 \\
-7 \cdot 079 \\
-0 \cdot 482 \\
-0.392 \\
-5 \cdot 275 \\
-2 \cdot 932 \\
-1 \cdot 116 \\
-0.482 \\
-1 \cdot 083\end{array}$ & $\begin{array}{l}-2 \cdot 735 \\
-2 \cdot 256 \\
-0.230 \\
-2 \cdot 429 \\
-0.216 \\
-0.162 \\
-1 \cdot 892 \\
-1 \cdot 258 \\
-0.448 \\
-0.216 \\
-0.314\end{array}$ & $\begin{array}{l}-0.952 \\
-0.348 \\
+0.009 \\
-0.648 \\
-0.086 \\
-0.061 \\
-0.610 \\
-0.549 \\
-0.163 \\
-0.086 \\
-0.063\end{array}$ & $\begin{array}{r}-0.228 \\
+0.148 \\
+0.027 \\
-0.033 \\
-0.020 \\
-0.013 \\
-0.172 \\
-0.170 \\
-0.036 \\
-0.020 \\
-0.003\end{array}$ \\
\hline CPh & $\begin{array}{r}8 \\
4 \\
0 \\
11 \\
15 \\
1 \\
0 \\
1\end{array}$ & $\begin{array}{r}-I I \cdot 343 \\
-4 \cdot 165 \\
-5 \cdot 933 \\
-5.696 \\
-1 \cdot 906 \\
-0.721\end{array}$ & $\begin{array}{c}-7.423 \\
-2.359 \\
-3.379 \\
-2.729 \\
-1.116 \\
-0.444\end{array}$ & $\begin{array}{l}-3.077 \\
-0.872 \\
-1.338 \\
-0.527 \\
-0.448 \\
-0.194\end{array}$ & $\begin{array}{l}-1.289 \\
-0.281 \\
-0.558 \\
+0.073 \\
-0.163 \\
-0.076\end{array}$ & $\begin{array}{l}-0.379 \\
-0.053 \\
-0.235 \\
+0.082 \\
-0.036 \\
-0.018\end{array}$ & $\begin{array}{l}9 \\
2 \\
1 \\
8 \\
6 \\
2 \\
1 \\
0\end{array}$ & $\begin{array}{l}-5.334 \\
-1.785 \\
-0.464 \\
-3.560 \\
-2.574 \\
-1.301 \\
-0.483\end{array}$ & $\begin{array}{l}-3.014 \\
-1.193 \\
-0.229 \\
-1.624 \\
-1.317 \\
-0.768 \\
-0.241\end{array}$ & $\begin{array}{l}-1.000 \\
-0.620 \\
-0.060 \\
-0.207 \\
-0.385 \\
-0.311 \\
-0.064\end{array}$ & $\begin{array}{l}-0.180 \\
-0.311 \\
-0.011 \\
-0.157 \\
-0.115 \\
-0.114 \\
-0.012\end{array}$ & $\begin{array}{r}+0.094 \\
-0.118 \\
-0.001 \\
-0.119 \\
-0.055 \\
-0.025 \\
0.001\end{array}$ \\
\hline
\end{tabular}


phosphatase, phosphoglucomutase, 6-phosphogluconate dehydrogenase, lactate dehydrogenase, serum cholinesterase $\mathrm{E}_{1}$ and $\mathrm{C}_{5}$, and adenylate kinase.

\section{Summary}

Tests with anti-Do on 755 unrelated people of Northern European ancestry are reported. The corresponding gene frequencies are:

$$
\begin{aligned}
& D o^{a}=0.420 \\
& D o=0.580
\end{aligned}
$$

The antigen $\mathrm{Do}^{\mathrm{a}}$ behaved as a dominant character in 201 Northern European families with 573 children and in 76 Israeli families with 224 children.

The locus responsible for the Dombrock system was found not to be closely linked to the loci responsible for the established blood group systems or to those for various biochemical characters of the blood.

Thanks are due to the following for their help: Dr. H. F. Polesky and Mrs. Jane Swanson for their generous supply of Mrs. Dombrock's serum; Professor H. Harris, F.R.S., and Dr. Elizabeth Robson of the Medical Research Council Human Biochemical Genetics Research Unit for tests for the biochemical characters; the many families of colleagues who gave their blood; Dr. A. Adam of Tel-Hashomer, Israel, Dr. A. de la Chapelle of Helsinki, and Dr. L. Went of Leiden, for collecting extra members of families who were not necessary for their own particular investigations; Dr. C. Salmon of Paris for samples from his original Auberger families; Miss Carolyn M. Giles of the Medical Research Council Blood Group Reference Laboratory for tests with anti$\mathrm{Yt}^{\mathrm{a}}$ and anti-Y $\mathrm{t}^{\mathrm{b}}$; the Sheffield and Glasgow Blood Transfusion Services for antiglobulin sera.

\section{REFERENCES}

Cook, P. J. L. (1965). The Lutheran-secretor recombination fraction in man: a possible sex difference. Ann. hum. Genet., 28, 393.

Fisher, R. A. (1939). Cited by Race, R. R., and Sanger, R. (1962) in Blood Groups in Man, 4th ed., p. II5. Blackwell Scientific Publications, Oxford.

Maynard Smith, S., Penrose, L. S., and Smith, C. A. B. (I96I). Mathematical Tables for Research Workers in Human Genetics. J. and A. Churchill, London.

Morton, N. E. (I955). Sequential tests for the detection of linkage. Amer. F. hum. Genet., 7, 277.

Polesky, H. F., and Swanson, J. L. (1966). Studies on the distribution of the blood group antigen $\mathrm{Do}^{\text {a }}$ (Dombrock) and the characteristics of anti-Do ${ }^{\mathrm{a}}$. Transfusion (Philad.), 6, 268.

Renwick, J. H., and Schulze, J. (I965). Male and female recombination fractions for the nail-patella : ABO linkage in man. Ann. hum. Genet., 28, 379.

Swanson, J. L., Polesky, H. F., Tippett, P., and Sanger, R. (1965). A 'new' blood group antigen, Do. Nature (Lond.), 206, 313.

Tippett, P., Sanger, R., Swanson, J., and Polesky, H. F. (1967). The Dombrock blood group system. In Proc.X Congr. europ. Soc. Haemat. In the press.

Webb, A. J., Lockyer, J. W., and Tovey, G. H. (1966). The second example of anti-Do ${ }^{\mathrm{a}}$. Vox Sang. (Basel), I1, 637. 